\title{
The copper pots and jam challenge
}

\author{
Hervé This
}

(C) Springer-Verlag Berlin Heidelberg 2012

We would like to invite you to participate in the Analytical Challenge, a series of puzzles to entertain and challenge our readers. This special "Analytical and Bioanalytical Chemistry" feature has established itself as a truly unique quiz series, with a new scientific puzzle published every other month. Readers can access the complete collection of published problems with their solutions on the ABC homepage at http:// www.springer.com/abc. Test your knowledge and tease your wits in diverse areas of analytical and bioanalytical chemistry by viewing this collection.

In the present challenge, copper and jellification is the topic. And please note that there is a prize to be won (a Springer book of your choice up to a value of $€ 75$ ). Please read on...

\section{Meet the challenge}

With the invention of devices for keeping food cool, cold or frozen, humankind has largely forgotten that our ancestors had to apply extensive knowledge to preserve food for a short or a long time [1]. First and foremost, cooking was, and still is, an efficient process for making microbiologically safe food. But cooking is also a means to obtain the most food from fresh plant or animal products, which undergo changes after slaughter or harvest as the living cells are not destroyed immediately on the harvest of an individual plant or the killing of an animal [2].

There are plenty of methods to extend the consumption lifetime of foods-salting [3], smoking [4], drying [5], fermenting [6] and preserving them in alcoholic, acidic or

\footnotetext{
H. This $(\square)$

Group of Molecular Gastronomy, INRA,

UMR 1145 AgroParisTech,

16 rue Claude Bernard,

75005 Paris, France

e-mail: herve.this@paris.inra.fr
}

alkaline solutions are common choices. Another process is preservation in sugar [7] owing to the fact that sucrose is efficient in halting the development of microorganisms [8] while giving a "good" taste- "good" meaning in this context that the food is recognized as the source of energy by primates, such as us [9]. It is also not widely known that we are the first generation not suffering from starvation [10], because of food preservation. In the past, summer was a time of plenty, with fruits falling from the trees, but winter was a time when food was scarce. And this is why preservation of food in sugar (or honey) was important.

Culinary books from the past give plenty of advice for making jams $[11,12]$ and other sugar-based preserves: the information was not superfluous, but necessary. Indeed, the information contained in recipes can be divided into three categories: definitions, additional technical information and all other information that is technically irrelevant [13]. Cookbooks indicate how to cook fruits with sugar and water, which is the definition of a jam. Then, as additional technical information (old wives' tales, tips, proverbs, etc.), many cookbooks also add that jams become firmer when the cooking is done in copper pots [14]. In this challenge, readers are asked to explain this culinary effect.

\section{The challenge}

The material from which cooking pans is made is important, and we often ignore that, for example, the invention of stainless steel at the onset of the twentieth century was remarkable progress. Some centuries ago, clay pots broke easily, cast-iron pans soon became rusty, copper could be covered with a layer of poisonous verdigris and copper lined with tin became damaged at high temperatures, thus requiring frequent replacement of the tin lining [14]. 
Concerning such additional culinary information [12], one should keep in mind the words of the French philosopher Bernard le Bouvier de Fontenelle (1657-1757) [15]:

Let's be sure of the fact before analysing the cause. It is true that this method is slow for most people who are rushing toward causes, but indeed we will avoid being ridiculous for having found the cause of some non-existing fact.

The experimental answer is not hard to obtain. Let us cook some fruit-orange, for example, with an equal amount of water for about $1 \mathrm{~h}$, and let us divide the resulting purée into two beakers. If we add copper sulphate $(1 \mathrm{~g})$ to one of the beakers, we can see clearly that the consistency of the mixture becomes much firmer. Why? Why do jams become firmer when cooked in a copper pot?

\section{References}

1. Dalton L (2002) Chem Eng News $80: 40$

2. Got F, Culioli J, Berge P, Vignon X, Astruc T, Quideau JM, Lethiecq M (1999) Meat Sci 51:35-42

3. Pinotti A, Graiver N, Califano A, Zaritzky N (2001) J Food Sci 67:2165-2171

4. Soldera S, Sebastianutto N, Bortolomeazzi R (2008) J Agric Food Chem 56:2727-2734

5. Kaya A, Aydin O, Demirtas C, Akgün M (2007) Desalination 212:328-343

6. Lesellier E (1990) Effet des conditions de séchage sur la stabilité des pigments caroténoïdes et sur la couleur des carottes déshydratées. $\mathrm{PhD}$ dissertation, University Paris VIII

7. Bernhard Wehr J, Menzies NW, Blamey FPC (2004) Food Hydrocolloids 18:375-378
8. Brocklehurst TF, Mitchell GA, Smith AC (1995) J Appl Bacteriol 78:495-500

9. Monneuse M-O, Hladik CM, Simmen B, Pasquet P (2011) Changes in food neophobia and food preferences during a weight reduction session: influence of taste acuity on the individual trajectory. In: Preedy VR, Watson RR, Martin CR (eds) Handbook of behavior, food and nutrition. Springer, New York, pp 1715-1727

10. Rigby N, James P (2003) Eurobesity, waiting for a green light for health? International Obesity TaskForce position paper, International Association for the Study of Obesity, London

11. Albert B (1838) Le cuisinier parisien. Ledentu, Paris

12. This H (2011) Cours de gastronomie moléculaire no 2: les précisions culinaires. Quae, Berlin

13. This H (2012) Pure Appl Chem. doi:10.1351/PAC-CON-12-01-01

14. Par les Dames Patronnesses de l'Oeuvre du Vêtement de Grammont (1905) 760 recettes de cuisine pratique. Grammont, p 193

15. Fontenelle BLB (1687) Histoire des oracles. First dissertation. Mortier, Amsterdam, chap 4

We invite our readers to participate in the Analytical Challenge by solving the puzzle above. Please send the correct solution to abc-challenge@springer.comby February 1, 2013. Make sure you enter "The copper pots and jam challenge" in the subject line of your e-mail. The winner will be notified by e-mail and his/her name will be published on the "Analytical and Bioanalytical Chemistry" website at $\mathrm{http} / / / \mathrm{www}$.springer.com/abc and in the journal (volume 405/issue 12) where the readers will find the solution and a short explanation.

The next Analytical Challenge will be published in 405/7, March 2013. If you have enjoyed solving this Analytical Challenge, you are invited to try the previous puzzles on the 'Analytical and Bioanalytical Chemistry' homepage. 